\title{
A Study on Innovation and Entrepreneurship Education Program in Application-oriented Colleges and Universities
}

\author{
Jinghong Wang \\ School of Economics and Management, Xi'an University, Xi'an City, Shaanxi Province, 710065, China
}

Keywords: Application-oriented colleges and universities; Innovation and entrepreneurship education; Education mode; Occupation ability

\begin{abstract}
Application-oriented colleges and universities are an important part of the development of higher education in china, therefore, strengthening the cultivation of innovative and entrepreneurial talents is an inevitable requirement for China's deepening educational reform. Application-oriented colleges and universities can further develop students' creative ability, professional quality and professional ability through innovation and entrepreneurship education, which will create a good beginning for students' future career. Based on the learning and practical experience, this paper firstly analyzed the significance of innovation and entrepreneurship education in application-oriented universities, and then discussed the status and problems of innovation and entrepreneurship education, and then put forward specific education programs.
\end{abstract}

\section{Introduction}

Since the Ministry of Education issued "opinions on promoting innovation and entrepreneurship education in colleges and universities and the work of college students' independent entrepreneurship" in 2010, the innovation and entrepreneurship education has been greatly developed and a lot of achievements have been made. However, innovation and entrepreneurship education has not yet made a fundamental breakthrough on a whole; an important reason is that there is no innovation and entrepreneurship education in colleges and universities from the height of the overall planning of personnel training. Therefore, it is necessary to make a thorough study of innovation and entrepreneurship education, and build a feasible educational program on the basis of grasping its significance.

\section{The Meaning of Innovation and Entrepreneurship Education in Application-oriented Colleges and Universities}

It is conducive to the realization of the goal of an innovative country. Improving the capability of independent innovation and building an innovative country is the core of the national development strategy and the key to improving the overall national strength. The party's eighteen report stressed the need to change ideas, encouraged entrepreneurship, and increased support for innovation and entrepreneurship training personnel. The key to building an innovative country is talent, and the foundation is education. The construction of an innovative country requires talents with innovative and entrepreneurial qualities; through the training of application-oriented talents with innovative thinking and entrepreneurial ability, application-oriented colleges and universities can serve the regional economic construction, thus promoting the construction of an innovative country.

It is conducive to the realization of the training target in application-oriented colleges and universities. The talents trained in application-oriented colleges and universities are different from the academic talents trained in research-oriented colleges and universities, and different from those trained by vocational colleges and universities. Personnel in cultivation of application-oriented 
colleges and universities is the talents who meet the needs of local economic construction and social development. Carrying out innovation and entrepreneurship education is beneficial for students to innovate and master the application technology, and to train innovative talents with distinctive characteristics, so as to realize the orientation of talent training in application-oriented colleges and universities.

It is conducive to the realization of self-development goals of college students. In the era of knowledge economy, college and university students have obvious characteristics of the times. They hope that their desire to realize their own value will be more and more intense through self employment. Strengthening the innovation and entrepreneurship education in application-oriented colleges and universities is conducive to the cultivation of college students' innovative ability, so as to provide conditions for their own development.

It is beneficial to relieve the employment pressure of college students. With the acceleration of the popularization of higher education, the overall scale of enrollment in colleges and universities in China has been expanding, and the number of graduates has been increasing year by year. According to preliminary statistics, college and university graduates in 2017 will reach 7 million 950 thousand. There is no increase in the number of jobs in the society compared with the increase in the number of graduates. Application-oriented colleges and universities can strengthen the innovation and entrepreneurship education, and actively guide and encourage students to participate in innovation and entrepreneurship practice to alleviate the increasing employment pressure, so that to start with employment and create more employment opportunities for the society and jobs.

\section{The Present Situation and Problems of Innovative Talents Training in Application-oriented Colleges and Universities}

The orientation of innovative talents training is not clear. For a long time, due to the influence and restriction of the traditional educational system and mechanism, the applied-oriented colleges and universities in China have adopted a highly centralized educational model. Although this kind of single talent training mode has trained a batch of specialized sharp talents for China in a certain period and development stage, its malpractice can not be ignored. On the one hand, it caused that the applied-oriented talents cultivation in Chinese colleges and universities is very similar to each other. To be specific, all colleges and universities adopt unified methods and steps in terms of education mode, teaching content and personnel training program. On the other hand, it made the talents trained by applied-oriented colleges and universities in our country present a very similar situation. The disadvantage of this talent training mode lies in the irrational cultivation of talents and the irrational structure of knowledge, and the comprehensive quality has obvious defects. This training mode mainly focuses on learning the theory knowledge; it is obviously insufficient in the fields of practical ability, practical ability, ability to adapt to the environment, team spirit and sense of innovation. It has a big gap with the training target of innovative and entrepreneurial talents in application-oriented colleges and universities. At present, with the deepening of the reform of higher education, the target of personnel training is gradually defined as application innovation. With strengthening the study of students' professional knowledge, application-oriented colleges and universities pay more attention to the training and training of students' practical training ability. On the whole, the definition of the target at knowledge, quality and ability is still not clear enough in application-oriented colleges and universities, which will affect the quality of talent training to some extent.

The goal of innovative talents training is not clear. For a long time, under the influence of the traditional education concept, Chinese application-oriented colleges and universities pay more attention to the students' theoretical knowledge, and they regard the teaching process simply as a process of accumulation of knowledge. In the student evaluation, they mainly master the knowledge as the main measure of the standard, ignoring the students' innovative ability and application ability training and stimulation. With the deepening of the reform of quality education, application-oriented colleges and universities urgently need to change the traditional educational concepts and break the shackles of traditional educational habits; they should no longer adhere to the old educational model 
and teaching methods, and pay more attention to the cultivation of students' innovative ability and innovative consciousness; in addition, they should pay attention to the combination of theory and practice, so that to improve the students' hands-on operation and practice level.

Innovative talent training mode is not scientific. The mode of talent training is the bridge connecting the guiding ideology of school running, the goal of running a school and the specific teaching work. It plays an important role in achieving the goal of personnel training. Talents training mode is influenced by many factors, such as school guiding ideology, school running thought and school running condition, etc. The mode of talent training is closely related to the scientific and perfect pre-service education and training system in China. In the introductory mode of education, the main status of students has not yet been truly respected and played. In class, the teacher teaches, and the student listens. The habit of passive acceptance of knowledge caused students' initiative and creativity being severely constrained. Therefore, it is particularly important and urgent to speed up the training mode of creative talents and good jobs in the research of personnel training mode under the new situation.

\section{Scheme of Innovation and Entrepreneurship Education in Application-oriented Colleges and Universities}

Set up the correct concept of innovation and Entrepreneurship Education. In order to realize the long-term development of innovation and entrepreneurship education, they must establish a correct concept of innovation and entrepreneurship education and carries on the reasonable localization to the innovation and entrepreneurship education. First of all, they should change "adaptive education" into "creative education". For a long time, traditional educational ideas have stifled the creativity of students. Application-oriented colleges and universities should build a broad platform for students, and guide students to change their ideas. According to the teaching level of the school, the application-oriented colleges and universities should bring the university students' self employment into the education of the school, and guide the whole process of educating people with the idea of innovation and entrepreneurship. Secondly, the application-oriented colleges and universities can learn from the advanced experience and learn from each other. Innovation and entrepreneurship education has developed rapidly in many provinces and municipalities. For example, some of them have perfect curriculum systems, and some have more complete service facilities. The practice system of innovation and entrepreneurship education has become mature, and application-oriented colleges and universities can improve their innovative and entrepreneurial education through learning from each other.

Rich forms of innovation and entrepreneurship education. First of all, application-oriented colleges and universities can make use of projects, science and technology funds and other platforms to carry out project guidance and achievement transformation, and establish entrepreneurial practices. Application-oriented colleges and universities can combine classroom teaching with practice, and train students to use knowledge to solve practical problems in practice. Further, application-oriented colleges and universities can rely on students' science and technology parks and make full use of enterprises as science and technology parks with opening up laboratories and other entrepreneurial practice bases. Based on practice base platform, application-oriented colleges and universities can carry out the study, visit and practice activities, so that to let students learn business knowledge and master entrepreneurial skills. Thirdly, they should organize the activities of college and university students' innovation and entrepreneurship seriously. They can discuss and exchange related questions about innovation and entrepreneurship through the "innovation and entrepreneurship" forum, entrepreneurship simulation competition, entrepreneurship, entrepreneurial experience exchange forum and other activities. Finally, application-oriented colleges and universities can also use the opportunity of college students during the summer and winter holidays to organize their students to practice in depth and to enhance their skills training in innovation and entrepreneurship.

Promote the integration of innovation, entrepreneurship education and professional education. First, changing education idea of the managers, educators and learners makes them 
realize that the integration of innovation and entrepreneurship education and professional education are the requirement of the social economy to the training of qualified personnel. It is also the requirement of higher education reform and further development. Secondly, they should reform the curriculum system, the teaching content and the training program. Moreover, they should bring innovation and entrepreneurship education into the personnel training program, and realize the deep integration of innovation, entrepreneurship education and professional education. Finally, they should establish a scientific and effective management and operation mechanism. They will combine innovation and entrepreneurship education with professional education. It involves teaching, administration and many other departments, as well as the construction and training programs of innovative and entrepreneurial practice bases both inside and outside the school, and the reform of the curriculum system. Therefore, application-oriented colleges and universities should improve the management and operation system, and realize the integration of innovation, entrepreneurship education and professional education.

Strengthen the construction of teachers team for innovation and entrepreneurship. In order to strengthen the innovation and entrepreneurship education and cultivate innovative talents, the application-oriented colleges and universities must train the team of teachers with innovative consciousness and innovative ability. First, they should pay attention to the cultivation of young teachers. They should regularly provide opportunities for entrepreneurial and young backbone teachers to participate in training and studying at home and abroad. They should support innovative teachers to participate in entrepreneurial practices and exercise in the enterprise, so as to improve the teacher's understanding of the practice of enterprise management. Second, they should pay attention to the introduction of talent. They should combine the actual situation of the school and employ experienced and successful people as part time tutors to make up for the weakness of the teachers' strength in innovation and entrepreneurship.

\section{Summary}

The innovation and entrepreneurship education of students in application-oriented colleges and universities is a systematic project, which requires the common concern of society, schools, families and teachers. In the specific education practice, teachers should discover and correct the problems existing in the innovation and entrepreneurship education in time, and mainly from the following aspects: Set up the correct concept of innovation and entrepreneurship education; enrich innovation and entrepreneurship education form; promote the integration of innovation, entrepreneurship education and professional education; strengthen innovation and entrepreneurship teachers team construction.

\section{Acknowledgements}

Shaanxi Education Science "13th Five-Year" program(2016) of Shaanxi Institute of Education: A Study on Innovation and Entrepreneurship Education in Local Application-oriented Colleges and Universities - Taking Xi'an University as an example(SGH16H217).

\section{References}

[1] Li Jun. Study and Practice of Entrepreneurship Education Model in Applied Undergraduate Colleges[J]. Journal of Xinyang College of Agriculture and Forestry, 2016, (04): 152-155.

[2] Wu Qingsong. Research on Entrepreneurship Education of Applied Undergraduate Students[J]. Journal of Heilongjiang Academy of Engineering, 2016, (04): 67-69+80.

[3] Yin Hong, Li Yongdan. Research on Entrepreneurship Education in Applied Undergraduate Universities[J]. Chinese University Students, 2013, (16): 60-64.

[4] Ding Bo, Ye Shujiang, Pu Ming. Research on Problems and Countermeasures of Innovation and Entrepreneurship Education in Applied Universities[J]. Journal of Heilongjiang Institute of 
Education, 2012, (05): 10-11.

[5] Meng Bo. Applied Undergraduate Colleges to Carry Out Entrepreneurship Education on the Internet[J]. Journal of Changsha Aeronautical Vocational and Technical College, 2011, (04): 9-11.

[6] Yuan Xingguo. The Training Model of Innovative and Entrepreneurial Talents in Applied Undergraduate Colleges[J]. Jiangsu Social Sciences, 2011, (S1): 20-23.

[7] Bao Guanyi. A Brief Analysis of the Mode of Entrepreneurship Education in Technological Application-oriented Colleges and Universities[J]. Reform and Opening up, 2009, (05): 186-187. 